Journal of Research in Technical Careers

May 2017, Vol. 1, No. 1.

(c) Author(s)

\title{
Iowa Agricultural Educators' Current and Perceived Grading Practices
}

\author{
Jenny Ann Lichty, Michael S. Retallick \\ Iowa State University
}

\begin{abstract}
Literature on grading reveals that grading practices have not changed much since they were first introduced. However, with alternative approaches, such as standards-based grading, being introduced, it is important to look at how agricultural educators are using grades to evaluate student learning. The purpose of this study was to determine the grading practices of Iowa high school agricultural educators. The accessible population consisted of 236 high school agricultural educators. Findings were based on responses of 157 (69.8\%) educators who responded to the study via an online questionnaire. These agricultural educators used a variety of learning approaches, and their beliefs aligned with their grading practices. They also based grades on more than just student learning, sometimes including items such as effort, responsibility, and attendance. This study serves as a starting point and building block to help agricultural educators develop grades that accurately portray a student's knowledge.
\end{abstract}

Keywords: grading, school-based agricultural education, student assessment, teacher practices

\section{Introduction}

Assigning a letter or numerical grade to student achievement is commonplace and for years has been a universal standard in education. Yet what the grade means in the traditional grading system is questionable. Though the valuable information of a grade is the details of the achievement on each learning goal, not the overall score (O'Connor, 2009), and the intent of grades is to describe the student's progress in a course (Dockery, 1995). Alpren (1960) acknowledged that the grade rarely represents true student accomplishment in terms of academic standards. "As soon as grades are introduced in schools, teachers, parents, and students emphasize grades rather than learning” (O’Connor, 2009, p. 17).

Grades often include examinations, quizzes, presentations, projects, homework, attendance, portfolios, participation, attitude, effort, and progress made, and teachers rely on various combinations of these elements to construct an overall grade (Guskey, 2009). These combinations give an unclear picture of student learning and fail to accurately articulate student achievement to parents (O’Connor, 2011). Such issues give cause for Brookhart's (2011) case that grades should be focused on what students learn-not what they earn.

The most logical reasons to grade students are those that help teachers teach and students learn. Wrinkle (1947) outlined four classifications of grades, which Airasian (1994) later updated to five purposes of grades: administrative purposes, student achievement feedback, guidance for students, instructional planning, and student motivation. Feedback and motivation seem to be most prevalent in the literature.

These purposes carry over into studies by Austin and McCann (1992) and Marzano (2000), who indicated educators and administrators viewed feedback about student achievement as the primary purpose of grading. Communicating student achievement is the primary purpose of grades (O’Connor, 2009) because "parents rely primarily on teacher-assigned grades when ascertaining the achievement of their children" (Randall \& Engelhard, 2010, p. 1372). Grades can be "clear communication vehicles, if there is a shared understanding of how they are determined and thus, what they mean" (O’Connor, 2009, p. 16).

While feedback has been viewed as one of the primary purposes, motivation as a purpose of grading is one of the most controversial aims. Grades given to motivate, punish, or sort students dilutes grade accuracy and usefulness and manipulates students (Wormeli, 2006). Guskey and Bailey (2001) reported that a student is not motivated by a D or 0 in the gradebook. Students distance themselves from learning, and educators must make extra effort to bring the students back (Wormeli, 2006).

Grades also influence college admissions and future opportunities. Even though many colleges and universities require achievement test scores and high 
school grade point average (GPA) as traditional admissions requirements (Mattern, Patterson, \& Wyatt, 2013), contradictory studies have reported the correlation of standardized admission examinations, such as the SAT or ACT with high school GPA. Studies by the United States Department of Education showed an increase in GPA between 2005 and 2009 (Nord et al., 2011). However, The College Board and ACT conducted studies showing that, although GPAs were higher than before, standardized test scores were lower than in previous years (Taylor, 2007). For example, an analysis of student SAT scores and GPAs in a Georgia high school showed a significant relationship between composite SAT scores and cumulative GPAs (Taylor, 2007).

Agricultural educators and other career and technical education (CTE) teachers are familiar with holding students accountable. "There has always been considerable emphasis on performance activities in instructing and assessing students in CTE” (Cutshall, 2001, p. 39). The Handbook on Agricultural Education in Public Schools outlines a variety of authentic and traditional forms of assessment, including record books, portfolios, self-reflections, debates, and presentations. Each assessment, graded with a rubric, becomes a reliable tool to measure student learning (Phipps, Osborne, Dyer, \& Ball, 2008). Many CTE teachers have used these tools for years; other teachers have recently begun using them (Cutshall, 2001). In agricultural education and other CTE areas, authentic assessment of practical application of academic knowledge comes naturally (Willhoft, 2013).

In a span of six years, CTE saw two versions of the Carl D. Perkins Act and a non-content-specific No Child Left Behind Act (NCLB). Requiring student achievement be put on paper, the 2006 Perkins Act also mandated educators to report "state-established, industry-validated career and technical skills” (Stone, 2009, p. 21). Technical skills were further defined as objectives and competencies required by a specific occupation (Stone, 2009). Technical skill attainment assesses each CTE student's knowledge, skills, and abilities to succeed in an occupation (Stone, 2009). By looking at where students are performing, determining a proficient level, and developing a plan on how to get there, CTE teachers can begin to use what is reported to improve their programs (Hoachlander, 2000).

The increased focus on skills and competencies by Perkins and NCLB caused an increased emphasis on performance activities associated with instructing and assessing CTE students (Cutshall, 2001). This discussion has gained traction outside of CTE, including a focus on standards-based education. The standards movement began as a result of a 1989 National Governor's Association summit on education where agreement was reached on the need for national education goals (Tucker \& Codding, 1998). Shortly thereafter, the National Council of Teachers of Mathematics released its national mathematics standards document.

Student assessment and teacher accountability have been prominent topics in the movement toward national standards and the ongoing dialogue in education about the need to identify learning goals for what every student should know and be able to do. Reporting of student grades is included in these conversations, yet very little research-based literature is available on grading student knowledge in agricultural education or other CTE areas. Research and literature on student assessment and grading within CTE has focused on changes in NCLB requirements and Perkins Act reauthorization. Furthermore, CTE research has focused on incorporating STEM and Core Curriculum into CTE curriculum (Haynes, Robinson, Edwards, \& Key, 2012; Hyslop, 2010; Pearson, Young, \& Richardson, 2013; Ulmer, Velez, Lambert, Thompson, Burris, \& Witt 2013; Wooten, Rayfield \& Moore, 2013). More information about agricultural educators' current grading practices is needed to understand how to move forward with new trends in grading and assessment.

\section{Conceptual Framework}

Research on teacher grading has focused primarily on practice. The theoretical frameworks were developed in only a few instances (Brookhart, 1994). One conceptual framework for grading is Natriello's (1987) model of evaluation processes in schools and classrooms. This circular model has eight stages: (a) establishing the purposes, (b) assigning tasks, (c) setting criteria, (d) setting standards, (e) sampling information, (f) appraising, (g) providing feedback, and (h) monitoring outcomes. The model provides the breadth needed to explore various assessments while establishing a framework for rigorous school and classroom assessments. Thus, Natriello's model of evaluation processes framed the assessment portion of this study.

Ajzen's (2012) theory of planned behavior framed the human (i.e., teacher) perspective of this study. This theory links beliefs and behaviors and serves as a framework for understanding and predicting human social behavior. Ajzen (2012) contended that behaviors and behavioral intentions are shaped by attitudes toward behaviors, subjective norms, and perceived behavior control. In this study, the theory of planned behavior helped frame teachers' grading behaviors as based on perceived behavior control of grading, attitudes toward grading, and norms associated with grading. These factors influence Natriello's (1987) evaluation processes and how teachers grade.

\section{Purpose and Objectives}

The purpose of this study was to determine the current grading practices and related rationale of Iowa's school-based agricultural educators. Three objectives guided this study:

1. To describe the purpose, definition, and components of grades;

2. To describe agricultural educators' grading practices; 
3. To identify the definitions and types of assessments used.

\section{Methods}

This study was part of a larger study focused on high school agricultural educators' grading practices and understanding of standards-based grading. We used a descriptive survey research design (Ary, Jacobs, and Sorensen, 2010) to collect and analyze the data. The population for this study consisted of all high school agricultural educators in Iowa $(\mathrm{N}=236)$. A list of current agricultural educators was obtained from the Iowa Agricultural Education Directory, which is hosted on the Iowa FFA Association website on behalf of the Iowa Department of Education.

A literature review revealed very few instruments to evaluate teachers' grading practices. Thus, we used instruments developed by Marzano (2000), Schmidt (2002), and Urich (2012) along with Brookhart's (2011) discussion statements as a foundation for designing an instrument to determine teachers' grading practices. The instrument was reviewed for content validity by two nonagricultural education instructors from area high schools using standards-based grading, a College of Education graduate assistant in educational research, and one professor in the Department of Agricultural Education and Studies at Iowa State University. A second group consisting of five out-of-state agricultural educators also reviewed the instrument for face validity. These agricultural educators were asked to evaluate the survey instrument and provide feedback regarding the format, question syntax, and implementation. Feedback was incorporated from both groups to increase content and face validity of the instrument.

We calculated Cronbach's alpha coefficients to determine the reliability of the instrument and performed a post-hoc reliability test. According to Ary, Jacobs, and Sorensen (2010), a modest reliability coefficient of .60 should be obtained for instruments used for research purposes. The reliability test for this study was calculated for grading beliefs and the Cronbach's alpha was .68 for grading beliefs and was considered acceptable (Ary et al., 2010).

Participants were contacted according to Dillman, Smyth, and Christian's (2009) recommendations for internet, mail, and mix-mode surveys to achieve high response rates. First, a pre-notice electronic message was sent describing the study's purpose and importance of responses. Next, we used Qualtrics to send each educator a unique link to the survey instrument through electronic messages. Reminder messages were sent electronically to nonrespondents two days and seven days after sending the initial correspondence. We sent a final notice 11 days after the first electronic message. Qualtrics ensured that only those who had not completed the survey instrument received reminder messages. A total of 165 educators (69.9\%) responded; the study had a usable response rate of $66.5 \%(\mathrm{n}=157)$. We compared early and late respondents to control for nonresponse error as recommended by Lindner, Murphy, and Briers (2001) and found no statistical differences between early and late respondents.

The instrument had three sections and included a variety of question types, including Likert-type, multiplechoice, multiple-select, short-answer, order-rank, and frequency items. The first section of the instrument explored educators' current grading practices and asked them to describe their grading beliefs and purposes. The second section of the instrument included general questions about extra credit, retesting, and accepting late work followed by more specific questions, making it easier for participants to respond (Ary, Jacobs, \& Sorensen, 2010). The last section focused on standardsbased grading. Participants also reported the number of standards taught and the standard sets used in their classrooms. In Iowa, a local-control state, no stateapproved agricultural education standards exist.

We calculated descriptive statistics, including frequencies, means, and standard deviations for this study. Open-ended questions were analyzed by using the open coding process recommended by Esterberg (2002).

\section{Findings}

All respondents $(n=157)$ were secondary agricultural educators employed by a high school in Iowa, although 52\% also reported teaching at least one middle school course. An equal number of respondents (25\%) were in their first three years of teaching high school agriculture courses or had been in the profession for more than 25 years. Similarly, 19\% of respondents had taught four to nine years or 10 to 15 years. Only $14 \%$ had taught high school agriculture for 16 to 25 years. Of the respondents, $40 \%$ were certified to teach at least one Curriculum for Agricultural Science Education (CASE) course.

Perceived Purpose, Definition, and Components of Grades. Respondents indicated their level of agreement with four statements regarding the purpose of grading (Table 1). These educators most strongly agreed that grades should reflect student achievement of intended learning outcomes. They also agreed that a grade should reflect an individual's achievement.

Respondents also agreed with a set of five statements regarding the purpose of grades in a traditional grading system (Table 2). These educators agreed that grades should be used to provide feedback about student learning to students and parents. They also indicated that grades should be used to make administrative decisions, such as advancing to the next course, class rank, and credits earned.

Respondents were provided with a list of the five most common grading components and asked to select all those they perceived should be included in a student's 
grade (Table 3). Most educators (95.1\%) indicated grades should include current knowledge, but only 50.3\% perceived grades should include prior knowledge.

Respondents also used a 5-point, Likert-type scale to indicate their agreement with statements about a traditional grading system. These educators most strongly agreed that academic achievement should be the primary basis for grades (Table 4). They also agreed that student effort and student behavior should contribute to grades.

Respondents were asked to define grades in their own words. Within the 137 definitions provided, 24 common terms and phrases were used. Definitions containing the terms know or knowledge were most common $(\mathrm{n}=20)$ including these three examples:

Table 1. Iowa Agricultural Educators Levels of Agreement with the Purposes of Grading

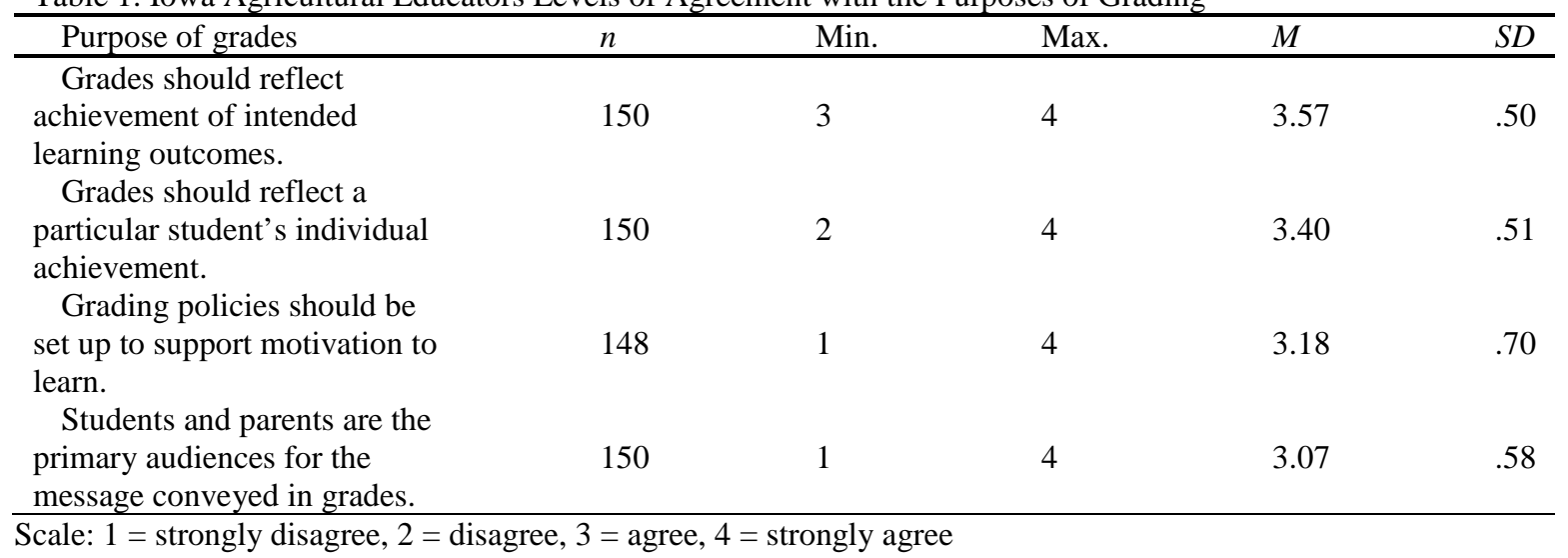

Table 2. Agricultural Educators’ Beliefs on the Purpose of Grades in a Traditional Grading System

\begin{tabular}{|c|c|c|c|}
\hline Grading statement in traditional grading systems & $n$ & $M$ & $S D$ \\
\hline Grades should be used to provide students and & & & \\
\hline $\begin{array}{l}\text { parents with feedback about student learning. } \\
\text { Grades should be used to make administrative }\end{array}$ & 125 & 4.13 & .74 \\
\hline decisions such as student's progress to the next & 125 & 3.81 & .75 \\
\hline course level, class rank, credits earned, etc. & & & \\
\hline $\begin{array}{l}\text { Grades should be used to motivate students. } \\
\text { Grades should be used to provide students with }\end{array}$ & 122 & 3.57 & .98 \\
\hline $\begin{array}{l}\text { guidance relative to courses they should take, } \\
\text { occupations they should consider, etc. }\end{array}$ & 125 & 3.53 & .82 \\
\hline Grades should be used to plan instruction. & 124 & 3.47 & 1.00 \\
\hline
\end{tabular}

Scale: 1 = not at all, 3 = somewhat, 5 = to a great extent

Table 3. Grading Components Agricultural Educators Perceived Should be Included in Student Grades $(\mathrm{n}=143)$

\begin{tabular}{lll}
\hline Components & $f$ & $\%$ \\
\hline Current knowledge & 136 & 95.1 \\
Effort & 124 & 86.7 \\
Responsibility & 99 & 69.2 \\
Prior knowledge & 72 & 50.3 \\
Attendance & 60 & 42.0 \\
\hline
\end{tabular}

Table 4. Distribution of means and standard deviations of agricultural educators' beliefs on grading criteria in a traditional grading system

\begin{tabular}{llll}
\hline Traditional Grading System Grading Criteria & $n$ & Mean & $S D$ \\
\hline Grades should be based on academic achievement. & 122 & 3.99 & 0.82 \\
Grades should be based on student effort. & 123 & 3.76 & 0.90 \\
Grades should be based on student behavior. & 126 & 2.94 & 1.18 \\
\hline
\end{tabular}

Scale: 1 = not at all, 3 = somewhat, 5 = to a great extent 
- “An indicator of where the student's knowledge is at this time."

- $\quad$ "A tool to help students understand where their knowledge base is in relation to my expectations and course expectations."

- "A measure of how well students know the material."

The second most commonly used terms were learn, learning, or learned. These terms were found in 18 responses including these three examples:

- "A caption of what a student has learned or provided evidence of knowledge learned based on outcomes and components taught in the classroom.”

- " "A measureable way to show student learning."

- " "A way to identify how students are learning and completing work."

The terms reflect or reflection were found in 15 responses. These terms were used with other words, such as learning, knowledge, or understanding. Other terms were used once with the following words: performance, comprehension, potential, assessment, and completion. Three examples are listed below:

- "Reflection of student's work and understanding of the material."

- “A scale to reflect student performance."
- $\quad$ "Reflection of what a student has learned in my course."

Requirement ( $n=14)$, achievement $(n=10)$, effort $(\mathrm{n}=10)$, level of competency/mastery $(\mathrm{n}=8)$, performance $(n=8)$, completion of work $(n=7)$, points earned $(n=7)$, content utilization/application $(n=6)$, and understand $(n=6)$ were mentioned often when defining grades. Other terms mentioned included snapshot $(n=5)$, rank $(\mathrm{n}=4)$, work ethic/responsibility $(\mathrm{n}=3)$, skills $(\mathrm{n}=$ $3)$, measuring stick $(\mathrm{n}=3)$, feedback/communication (n $=3)$, motivation $(n=2)$, progress $(n=2)$, ability to regurgitate $(n=2)$, needed for college/scholarships $(n=$ $2)$, attitude $(n=1)$, and potential $(n=1)$.

Actual Grading Practices. Respondents $(n=157)$ identified what grades reflect in their classrooms. The most common response was knowledge ( $\mathrm{n}=148,94.3 \%$ ), followed by effort $(n=135,86.0 \%)$ and responsibility ( $\mathrm{n}$ $=118,75.2 \%)$. Attendance also influenced grades in $49.0 \%$ ( $\mathrm{n}=77$ ) of respondents' classrooms. Ranking students or grading performance in relation to their peers was lowest at $43.4 \%(n=68)$.

Respondents further explained grades in their classrooms with written explanations $(\mathrm{n}=131)$, which were organized into six categories: student behavior $(\mathrm{n}=$ 46), knowledge $(\mathrm{n}=36)$, involvement/participation $(\mathrm{n}=$

Table 5. Terms and Phrases Used to Describe Circumstances in which Agricultural Educators Offered Students the Opportunity to Retake or Retest $(\mathrm{n}=108)$

\begin{tabular}{ll}
\hline Circumstances & $f$ \\
\hline Low class performance & 22 \\
Absence & 15 \\
Student explanation and development of relearning plan & 14 \\
Effort & 10 \\
School policy & 8 \\
Special education, 504 plan, IEP & 7 \\
No limits to retakes/retests & 7 \\
Limited number of retakes/retests & 4 \\
Limited retake grade/percent & 4 \\
Teacher initiated & 4 \\
Course specific & 2 \\
Limited retake time window & 2 \\
\hline
\end{tabular}

Table 6. Circumstances and Requirements Under Which Agricultural Educators Accepted Late Work $(\mathrm{n}=125)$

\begin{tabular}{ll}
\hline Circumstances & $f$ \\
\hline Time restriction & 45 \\
Grade restriction & 30 \\
Absence & 24 \\
School policy & 18 \\
Time and grade restriction & 14 \\
No restrictions or circumstances & 12 \\
Teacher arranged & 8 \\
Teacher discrepancy & 5 \\
Effort & 3 \\
Failed to complete the first time & 1 \\
\hline
\end{tabular}


Journal of Research in Technical Careers

Table 7. Extra Credit Opportunities Offered by Iowa Agricultural Educators $(n=103)$

\begin{tabular}{ll}
\hline Extra credit opportunity & $f$ \\
\hline Additional content activities & 49 \\
Out-of-class activities & 33 \\
FFA Participation & 11 \\
Non-content items & 9 \\
Chores & 4 \\
Community service & 2 \\
SAE record books & 2 \\
Correcting answers & 2 \\
\hline
\end{tabular}

Table 8. Use of Formative and Summative Assessments by Agricultural Educators $(\mathrm{n}=149)$

\begin{tabular}{lll}
\hline Type of assessments used & $f$ & $\%$ \\
\hline Both but more formative assessments & 94 & 63.1 \\
Both but more summative assessments & 41 & 27.5 \\
Formative assessments only & 11 & 7.4 \\
Summative assessments only & 3 & 2.0 \\
\hline
\end{tabular}

Table 9. Types of Assessment Used by Iowa Agricultural Educators $(\mathrm{n}=149)$

\begin{tabular}{llll}
\hline Assessment type & $n$ & $M$ & $S D$ \\
\hline Individual projects & 139 & 3.97 & 0.92 \\
Written papers & 141 & 3.97 & 1.37 \\
Group projects & 140 & 3.87 & 1.01 \\
Hands-on assessments & 138 & 3.83 & 0.90 \\
Written examinations & 136 & 3.82 & 0.95 \\
Rubrics & 138 & 3.81 & 1.01 \\
Student self-assessment & 138 & 3.49 & 1.46 \\
Oral examinations & 136 & 3.04 & 1.61 \\
Portfolios & 134 & 2.07 & 1.43 \\
Standardized examinations & 138 & 2.05 & 1.50 \\
\hline
\end{tabular}

Scale: $1=$ never used, $2=$ less than once a semester, $3=1$ to 3 times a semester, $4=4$ to 7 times a semester, $5=5$ to

8 or more times a semester

32), understanding $(n=29)$, achievement $(n=25)$, and performance $(\mathrm{n}=17)$.

Of the 157 respondents, $75 \%(n=148)$ offered students the opportunity to retest. These educators reported offering retakes and retests for a variety of reasons (Table 5). A total of 108 responses were analyzed, and 13 common phrases or terms were used to describe these circumstances. The most frequent circumstance for offering a retake or retest was low individual performance $(n=40)$.

Respondents also reported circumstances for which late work would be accepted (Table 6). Time and grade restrictions, absences, and school policies were among the most frequent reasons for accepting late work.

Respondents were asked to indicate the frequency with which they provided extra credit. Slightly less than one-half ( $n=69,46 \%$ ) of these educators rarely offered extra credit, and $27.5 \%(n=41)$ sometimes offered extra credit. Only $2 \%(n=3)$ of respondents offered extra credit often, and only one respondent offered extra credit all the time. About one-quarter of the respondents $(n=35$, 23.5\%) did not provide opportunities for extra credit.
Some respondents $(n=103)$ provided a written explanation for offering extra credit. Those statements were summarized into eight categories (Table 7). Additional content activities were most common $(n=49)$. Examples of additional content activities included extra problems, supplemental worksheets, key terms research, project-based activities, or additional presentations.

Assessment Practices. Respondents were asked to define assessment in their own words. They provided 116 definitions from which nine themes emerged. The most frequent definition was a measurement of learning ( $\mathrm{n}=$ 55, 47.7\%). Other definitions included a measurement of understanding ( $\mathrm{n}=16,13.8 \%$ ), a measurement of application ( $\mathrm{n}=9,7.7 \%)$, and a measurement of performance $(n=6,5.2 \%)$. Four respondents $(n=4$, $3.4 \%$ ) described assessment as a measuring device, and two ( $\mathrm{n}=2,1.7 \%)$ perceived assessments as a means to compare a student to their peers. Others defined assessment as a test $(n=10,8.6 \%)$ or reflection of student work $(n=2,1.7 \%)$. 
Most respondents reported using both formative and summative assessments with a greater focus on formative assessments (63.1\%); only 7.4\% used only formative assessments (Table 8). Slightly more than one-quarter (27.5\%) of respondents reported using both types of assessment with more focus on summative assessments, and only $2.0 \%$ used summative assessments alone.

In Iowa agricultural education, there are not a required job-ready tests used or a required set of standards teachers must follow. Respondents also reported how often they used various types of assessments (Table 9). Individual projects and written papers were used most frequently, followed by group projects. Portfolios and standardized examinations were used least.

\section{Conclusions, Recommendations, and Implications}

This study revealed varying grading practices among agricultural educators in Iowa. This finding aligns with results of Fisher, Frey, and Pumpian (2011), who argued that grades are "an amalgam of homework, classroom behavior, quizzes, projects, and tests" (p. 46), and Guskey (2009), who reported that a combination of academic and nonacademic elements lead to an overall grade. Respondents in this study perceived that academic achievement should be the primary basis for grades, but they also saw value in including nonacademic elements such as motivation, effort, responsibility, and student behavior. This leads to a lack of clarity about the level of student achievement in regards to course content, a concern echoed by O’Connor (2011).

Iowa agricultural educators' practices, as expressed, were consistent with their beliefs about grading. More than three-fourths of respondents used effort and responsibility as grading criteria, and nearly one-half included attendance as a grading criterion. Nonacademic criteria were as prevalent as academic criteria. When respondents used their own words to define grades, they rarely mentioned effort, but $86.7 \%$ of these educators perceived effort should be included. In addition, nearly three-quarters of respondents offered extra credit, much of which was nonacademic in nature.

At face value, these conclusions should raise concern. Grading based on effort, behavior, and attendance is problematic, especially from an academic perspective. Any academician would expect student grades to focus on student learning and students' ability to demonstrate they have mastered the appropriate standards. However, a valid argument for including nonacademic and behavioral-based criteria for CTE. In addition to academics, CTE also focuses on career readiness and 21st century skills (Bray, Green, \& Kay, 2010).

While those in CTE would argue that academic standards, career readiness, and 21st century skill development align well and can be taught in conjunction with one another, grading these elements and reporting only one overall grade is a problem. Grades may be the only means to measure career readiness, as state standards and assessment generally do not reflect the knowledge and skills needed for student success in college and careers (ACT, 2006). Yet when career and 21st century skills are incorporated into the grade, confusion as to what the grade means or measures arises. The fundamental problem may be that a single letter grade or percentage cannot clearly reflect all of these elements.

These issues and the findings of this study suggest that a broader discussion about grading is needed. Central to this discussion is the appropriateness of a single letter grade for measuring student learning and career readiness in CTE. The movement toward standards-based education signals such a need, as has the development of CASE, a curriculum built around assessment elements and desired outcomes that presents students with clear and concise learning objectives and expectations with hands-on learning (Curriculum for Agricultural Science Education, 2013). Because of the inquiry-based nature of the CASE curriculum, grading has been identified as a concern of CASE educators (Lambert, Velez, \& Elliot, 2014). This discussion is of particular interest in Iowa because nearly one-half of the state's high school agricultural educators have less than 15 years of experience and more than $70 \%$ have CASE certifications.

Though standard definitions exist for the term grades, asking educators to define the term provides insight into their grading philosophy. Collectively, agricultural educators in this study defined grades as a reflection of student learning and knowledge that is a required part of education. To hold programs accountable and attain statewide consistency, agricultural educators, as a group, should develop an agreement regarding what a grade includes and the best method to communicate student achievement.

Defining grades for agricultural education would be easier if grades in agricultural education had a clear purpose. This study revealed no overarching purpose for grades as the responses to purpose statements from the literature did not reveal strong agreement or disagreement from respondents. These agricultural educators agreed that motivation is a purpose for grades, but scholars would disagree. Have points and percentages become a reward and motivation system for students rather than tools to communicate levels of learning or mastering skills? If yes, students will not ask what they did wrong or how they can improve but what extra credit can they do to gain more points. Many agricultural educators in this study agreed that grades should be used as a feedback mechanism, but the feedback needs to clearly indicate what students know and not how many points they can accumulate because of extra credit.

One bright spot of this study is that respondents not only used both formative and summative assessments but also emphasized formative assessment. This is appropriate according to same literature (e.g. Stecker, 
Fuchs, and Fuchs, 2005). These agricultural educators used a variety of learning experiences and approaches in their classrooms that impact students' grades, and they used hands-on activities and real-life problems more than lecture and standardized tests. This is consistent with literature that indicates the need for an emphasis on performance activities and an increase in authentic assessments (Brookhart, 2011; Cutshall, 2001; O’Connor, 2009; Willhoft, 2013).

This study has implications for agricultural educators in Iowa as well as agricultural teacher education programs nationwide. A key issue has emerged: In agricultural education, what do grades really mean and what do they measure? Not only are students, parents, and external stakeholders uncertain, inconsistencies among agricultural educators also exist. Iowa agricultural educators need to create a shared purpose and understanding of agricultural education grading. This could occur through ongoing professional development or perhaps by constructing a professional learning community for agricultural educators interested in improving their grading practices. Either way, agricultural educators should consider following an effective evaluation framework similar to the one provided by Natriello (1987).

We encourage agricultural teacher education programs to not only include grading strategies as part of the curriculum, but also advance the discussion about what a single grade or percentage in a class really means and communicates to students, parents, and other stakeholders. Teacher education programs must go beyond teaching various formative and summative assessment strategies. Educators need to know these strategies, but they must also understand how those assessments contribute to and affect grades. Given the competency-based nature of agricultural education and CTE and the overall movement toward standards-based education, it is crucial that these conversations begin now and are ongoing.

Additional research on grading practices is needed. Similar studies should be conducted to determine agricultural education grading practices in other states, especially those that have established and required curriculum standards. We should also study perceptions of educators in other content areas such as math, English, and science about grading practices and content standards. These findings will help create a better understanding of the needs of the entire secondary education system. And because agricultural educators have experience implementing educational reforms, e.g., technical skill attainment required by the Perkins Act and already use many hands-on activities and other authentic learning assessments, perhaps they can provide guidance to educators in other disciplines who are beginning to use these approaches more frequently.

Note: This research paper is a product of the Iowa Agriculture and Home Economics Experiment Station,
Ames, Iowa. Project No. 3813 and sponsored by Hatch Act and State of Iowa funds.

\section{References}

ACT, Inc. (2006). Ready for college and ready for work: Same or different? Iowa City, IA: Author. Retrieved from

http://www.act.org/research/policymakers/pdf/Read inessBrief.pdf

Airasian, P. W. (1994). Classroom assessment. New York, NY: McGraw-Hill.

Ajzen, I. (2012). The theory of planned behavior. In P. Van Lange, A. W. Kruglanski, \& E. T. Higgins (Eds.), Handbook of theories of social psychology: Volume 1 (pp. 438-459). London, England: SAGE Publications. doi:10.4135/9781446249215

Alpren, M. (1960). A fair grading system. The Clearing House, 35(2), 113-114.

Ary, D., Jacobs, L. C., \& Sorensen, C. (2010). Introduction to research in education (8th ed.). Belmont, CA: Wadsworth.

Austin, S., \& McCann, R. A. (1992, April). Here's another arbitrary grade for your collection: A statewide study of grading policies. Philadelphia, PA: Research for Better Schools.

Bray, J. B., Green, K. A., \& Kay, K. (2010). Up to the challenge: The role of career and technical education and 21st century skills in college and career readiness. Retrieved from http://www.p21.org/documents/CTE_Oct2010.pdf

Brookhart, S. M. (1994). Teachers' grading: Practice and theory. Applied Measurement in Education, 7(4), 279-301.

Brookhart, S. M. (2011). Starting the conversation about grading. Educational Leadership, 69(3), 10-14.

Curriculum for Agricultural Science Education. (2013). The CASE Difference. Retrieved November 13, 2016, from http://www.case4learning.org/index.php/aboutcase/the-case-difference/the-case-difference

Cutshall, S. (2001, April). Don't worry, this is only a test. Techniques, 76, 39.

Dillman, D. A., Smyth, J. D., \& Christian, L. M. (2009). Internet, mail, and mixed-mode surveys: The tailored design method (3rd ed.). Hoboken, NJ: Wiley \& Sons.

Dockery, E. R. (1995). Better grading practices. Education Digest, 60(5), 34-36.

Esterberg, K. G. (2002). Qualitative methods in social research. Boston, MA: McGraw Hill.

Fisher, D., Frey, N., \& Pumpian, I. (2011). No penalties for practice. Educational Leadership, 69(3), 46-51.

Guskey, T. R. (2009). Practical solutions to serious problems in standards-based grading. Thousand Oaks, CA: Corwin Press. 
Guskey, T. R., \& Bailey, J. M. (2001). Developing grading and reporting systems for student learning. Thousand Oaks, CA: Corwin Press.

Haynes, J. C., Robinson, J. S., Edwards, M. C., \& Key, J. P. (2012). Assessing the effect of using a science-enhanced curriculum to improve agriculture students' science scores: A causal comparative study. Journal of Agricultural Education, 53(2), 15-27. doi:10.5032/jae.2012. 02015

Hoachlander, G. (2000, February 1). Make a tool of the rules. Techniques, 75, 1-4.

Hyslop, A. (2010, March 1). CTE's role in science, technology, engineering and mathematics. Techniques, 85, 3.

Lambert, M. D., Velez, J. J., \& Elliot, K. M. (2014). What are the teachers' experiences when implementing the Curriculum for Agricultural Science Education? Journal of Agricultural Education, 55(4), 100-115. doi:10.5032/jae.2014.04100

Lindner, J. R., Murphy, T. H., \& Briers, G. E. (2001). Handling nonresponse in social science research. Journal of Agricultural Education, 42(4), 43-53. doi:10.5032/jae.2001.04043

Marzano, R. J. (2000). Transforming classroom grading. Alexandria, VA: Association for Supervision and Curriculum Development.

Mattern, K. D., Patterson, B. F., \& Wyatt, J. N. (2013). How useful are traditional admission measures in predicting graduation within four years? The College Board. Retrieved from http://research.collegeboard.org/sites/default/files/p ublications/2013/9/researchreport-2013-1-howuseful-traditional-measures-graduation.pdf

Natriello, G. (1987). The impact of evaluation processes on students. Educational Psychologist, 22(2), 155175. doi:10.1207/s15326985ep2202_4

Nord, C., Roey, S., Perkins, R., Lyons, M., Lemanski, N., Brown, J., and Schuknecht, J. (2011). The nation's report card: America's high school graduates (NCES 2011-462). U.S. Department of Education, National Center for Education Statistics. Washington, DC: U.S. Government Printing Office.

O'Connor, K. (2009). How to grade for learning, K-12 (3rd ed.). Thousand Oaks, CA: Corwin.

O’Connor, K. (2011). A repair kit for grading: 15 fixes for broken grades (2nd ed.). Boston, MA: Pearson.

Pearson, D., Young, R. B., \& Richardson, G. (2013). Exploring the technical expression of academic knowledge: The science-in-CTE pilot study. Journal of Agricultural Education, 53(2), 162-179. doi:10.5032/jae.2013.04162
Phipps, L. J., Osborne, E. W., Dyer, J. E., \& Ball, A. (2008). Handbook on agricultural education in public schools (6th ed.). Clifton Park, NY: Thomson Delmar Learning.

Randall, J., \& Engelhard, G. (2010). Examining the grading practices of teachers. Teaching and Teacher Education, 26(7), 1372-1380.

Schmidt, R. (2002). Colorado middle school teacher practices of blending standards-based education with middle school integrative curricular practice and philosophy (Doctoral dissertation). Retrieved from ProQuest Digital Dissertations. (AAT 3060047)

Stecker, P. M., Fuchs, L. S., \& Fuchs, D. (2005). Using curriculum-based measurement to improve student achievement: Review of research. Psychology in the Schools, 42, 795-819.

Stone, J. R. (2009, February 1). A Perkins challenge: Assessing technical skills in CTE. Techniques, 84, 21-23.

Taylor, A. C. (2007). Grade inflation: An analysis of teacher perception, grade point average, and test scores in one southeastern Georgia high school (Doctoral dissertation). Georgia Southern University, Statesboro, GA. Retrieved from DigitalCommons@Georgia Southern.

Tucker, M., \& Codding, J. (1998). Standards for our schools: How to set them, measure them, and reach them. San Francisco, CA: Jossey-Bass.

Ulmer, J., Velez, J., Lambert, M., Thompson, G., Burris, S., \& Witt, P. (2013). Exploring science teaching efficacy of CASE curriculum teachers: A post-thenpre assessment. Journal of Agricultural Education, 53(2), 121-133. doi:100.5032/jae.2013.04121

Urich, L. J. (2012). Implementation of standards-based grading at the middle school level (Doctoral dissertation). Retrieved from ProQuest Digital Dissertations. (AAT 3511484)

Willhoft, J. (2013, April 1). The Common Core and next-generation assessments: Preparing students for CTE. Techniques, 88, 38-41.

Wooten, K., Rayfield, J., \& Moore, L. (2013). Identifying STEM concepts associated with junior livestock projects. Journal of Agricultural Education, 54(4), 30-43. doi:10.5032/jae.2013.04030

Wormeli, R. (2006). Fair isn't always equal: Assessing \& grading in the differentiated classroom. Portland, ME: Stenhouse.

Wrinkle, W. L. (1947). Improving marking and reporting practices in elementary and secondary schools. New York, NY: Rinehart. 